\title{
Leptomeningeal Disease in Glioblastoma: Endgame or Opportunity?
}

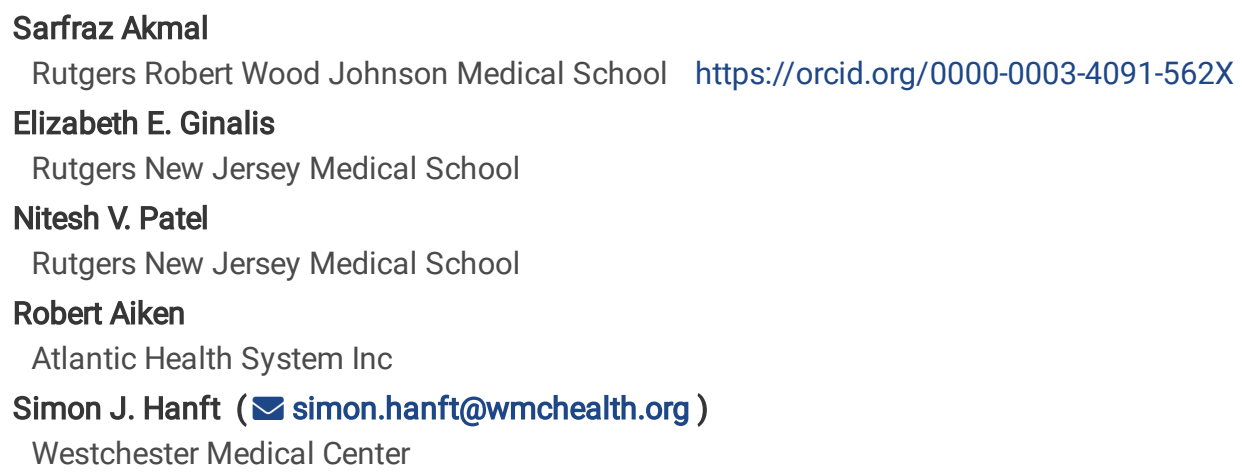

\section{Research Article}

Keywords: Glioblastoma multiforme, leptomeningeal disease, leptomeningeal metastasis, neuro-oncology

Posted Date: August 17th, 2021

DOI: https://doi.org/10.21203/rs.3.rs-805110/v1

License: (c) (i) This work is licensed under a Creative Commons Attribution 4.0 International License. Read Full License

Version of Record: A version of this preprint was published at Journal of Neuro-Oncology on October 8th, 2021. See the published version at https://doi.org/10.1007/s11060-021-03864-x. 


\section{Abstract}

Introduction: Glioblastoma is an aggressive cancer with a notoriously poor prognosis. Recent advances in treatment have increased overall survival, though this may be accompanied by an increased incidence of leptomeningeal disease (LMD). LMD carries a particularly severe prognosis and remains a late stage manifestation of glioblastoma without satisfactory treatment. The objective of this review is to survey the literature on treatment of LMD in glioblastoma and to more fully characterize the current therapeutic strategies.

Methods: The authors performed a systematic review following PRISMA criteria on PubMed. Articles that included adult patients with LMD from glioblastoma multiforme were retrieved and reviewed.

Results: LMD in glioblastoma patients is increasing in incidence, with reports of up to $21 \%$. The overall survival without treatment is alarmingly brief, with patients surviving between 1.6-3.8 months. All studies showed that treatment does improve overall survival significantly, increasing to 11.7 months in one study. However, no one adjuvant or surgical therapy has been shown to improve survival in LMD significantly over another. Direct treatment methods include chemotherapy (standard, anti-angiogenic, intrathecal, immunotherapy), and radiation. Hydrocephalus is a complication in LMD that can be treated with ventriculoperitoneal shunt placement, however treating hydrocephalus and delivering intrathecal chemotherapy is a challenge.

Conclusion: Though evidence remains lacking and there is no consensus, treatments show a trend towards improving survival and should be considered on a case-by-case basis. Further studies are necessary in the pursuit of a standard of care.

\section{Introduction}

Glioblastoma multiforme (GBM) is the most aggressive and common type of primary brain cancer among adult patients. GBM is a tumor that arises from the cells responsible for supporting the blood-brain barrier, providing nutrients to nervous tissue, maintaining ion balance, supporting nerve conduction, and repairing the brain after injury [1]. It is characterized by a rapidly fatal course with a roughly 1-year median survival after primary diagnosis [2]. In the face of such poor outcomes, the scientific community has developed and studied several multidisciplinary treatment options. However, these have minimally extended survival time to date. Maximal surgical resection followed by adjuvant radiotherapy and temozolomide offers the best chance at prolonging survival time, yet this has to be carefully weighed against quality of life and the patient's wishes [3].

Leptomeningeal disease (LMD) is a complication of advanced cancer in which malignant cells infiltrate the meningeal covering of the brain or spinal cord either through direct invasion or through cerebrospinal fluid (CSF) spread. In recent years, there has been an increase in reporting of LMD in patients with GBM. LMD carries a very severe prognosis, with $75 \%$ of patients dying within 18 months of diagnosis [4]. Therefore, it is important to clearly define the current therapeutic strategies and whether they confer any survival benefit.

\section{Methods}

We conducted a systematic review following Preferred Reporting Items for Systematic Reviews and Meta-Analysis (PRISMA) guidelines for quantitative analysis as shown in Fig. 1. A search on PubMed using the search terms ["glioblastoma multiforme" and "leptomeningeal dissemination"], ["glioblastoma multiforme" and "leptomeningeal spread"], and ["glioblastoma multiforme" and "leptomening*"] between the years 1950 and 2020 was performed. Our inclusion criteria included articles reporting on adult patients diagnosed with LMD from glioblastoma multiforme. We excluded any articles written in non-English languages and any pediatric cases. Next, we further filtered our search to include studies that stratified patients based on the presence of LMD. Studies that measured LMD only as a dependent variable or did not stratify patients based on presence of LMD were excluded from quantitative analysis.

After selection of the relevant studies, data was extracted on patient demographics, treatment, time course of LMD diagnosis and survival. Patient demographics recorded included the number of patients included in the study and median age. We recorded the time from tumor diagnosis until LMD diagnosis, treatment upon LMD diagnosis, KPS score pre- and post-intervention, progression free survival, survival on intervention, and overall survival.

\section{Results}

After the initial search, 188 total articles were retrieved for screening and 18 were removed after screening for duplicates. After titles and abstracts were screened, 111 articles were removed as per the exclusion criteria. 59 full texts were screened of which 23 were excluded from quantitative analysis due to study design or patient population features. This left 36 articles selected for data retrieval. After data retrieval, 18 articles were excluded as they did not record our targeted patient characteristics. Ultimately, 18 articles met final criteria for data retrieval. 
Among these articles, 3 case series, 12 case reports, and 3 retrospective reviews were included. Features of these studies are presented in Table 1. 
Table 1

Study Characteristics and Outcomes of Included Articles

\begin{tabular}{|c|c|c|c|c|c|c|c|c|c|}
\hline $\begin{array}{l}\text { Study Author } \\
\text { (Year) }\end{array}$ & $\begin{array}{l}\text { Number } \\
\text { of } \\
\text { Patients } \\
\text { with } \\
\text { LMD in } \\
\text { GBM }\end{array}$ & $\begin{array}{l}\text { Median } \\
\text { Age } \\
\text { (Years) }\end{array}$ & $\begin{array}{l}\text { Median } \\
\text { Time to } \\
\text { LMD } \\
\text { diagnosis } \\
\text { (Months) }\end{array}$ & $\begin{array}{l}\text { Treatment } \\
\text { upon LMD } \\
\text { Diagnosis: \# of } \\
\text { patients (\%) }\end{array}$ & $\begin{array}{l}\text { Median } \\
\text { KPS }\end{array}$ & $\begin{array}{l}\text { Median } \\
\text { KPS Post } \\
\text { Intervention }\end{array}$ & $\begin{array}{l}\text { Median } \\
\text { Progression } \\
\text { Free } \\
\text { Survival } \\
\text { (Months) }\end{array}$ & $\begin{array}{l}\text { Median } \\
\text { Survival } \\
\text { Upon } \\
\text { Intervention } \\
\text { (Months) }\end{array}$ & $\begin{array}{l}\text { Median } \\
\text { Overall } \\
\text { Survival } \\
\text { (Months) }\end{array}$ \\
\hline $\begin{array}{l}\text { Lam et al. } \\
(1991)\end{array}$ & 1 & 68 & 8.0 & $\begin{array}{l}\text { Radiation: } 1 \\
(100)\end{array}$ & N/A & $\mathrm{N} / \mathrm{A}$ & $\mathrm{N} / \mathrm{A}$ & 0 & 8.0 \\
\hline $\begin{array}{l}\text { Lindsay et al. } \\
(2002)\end{array}$ & 1 & 42 & 31.0 & $\begin{array}{l}\text { Chemo, } \\
\text { Radiation: } 1 \\
(100)\end{array}$ & N/A & $\mathrm{N} / \mathrm{A}$ & $\mathrm{N} / \mathrm{A}$ & 17.0 & 48.0 \\
\hline $\begin{array}{l}\text { Inamasu et } \\
\text { al. (2003) }\end{array}$ & 1 & 56 & 4.0 & $\begin{array}{l}\text { VP Shunt: } 1 \\
(100)\end{array}$ & 50 & 60 & $\mathrm{~N} / \mathrm{A}$ & 2 & 6 \\
\hline \multirow{2}{*}{$\begin{array}{l}\text { Shah et al. } \\
(2010)\end{array}$} & \multirow[t]{2}{*}{2} & 1. 51 & 1. 1.5 & $\begin{array}{l}\text { 1.Radiation: } 1 \\
(50)\end{array}$ & \multirow[t]{2}{*}{$\mathrm{N} / \mathrm{A}$} & \multirow[t]{2}{*}{ N/A } & \multirow[t]{2}{*}{ N/A } & 1. 1.0 & 1. 2.5 \\
\hline & & 2. 22 & 2. 3.0 & $\begin{array}{l}\text { 2. No } \\
\text { treatment: } 1 \\
(50)\end{array}$ & & & & 2. 0.25 & 2. 3.25 \\
\hline $\begin{array}{l}\text { Witoonpanich } \\
\text { et al. (2011) }\end{array}$ & 1 & 64 & 0 & $\begin{array}{l}\text { No treatment: } 1 \\
(100)\end{array}$ & $\mathrm{N} / \mathrm{A}$ & N/A & N/A & 3.0 & 3.0 \\
\hline $\begin{array}{l}\text { Amitendu et } \\
\text { al. (2012) }\end{array}$ & 1 & 47 & 7.0 & $\begin{array}{l}\text { Radiation: } 1 \\
(100)\end{array}$ & $\mathrm{N} / \mathrm{A}$ & N/A & N/A & 1.0 & 8.0 \\
\hline $\begin{array}{l}\text { Grah et al. } \\
(2013)\end{array}$ & 1 & 59 & 4.0 & $\begin{array}{l}\text { Radiation: } 1 \\
(100)\end{array}$ & $\mathrm{N} / \mathrm{A}$ & $\mathrm{N} / \mathrm{A}$ & N/A & 1.0 & 5.0 \\
\hline \multirow[t]{6}{*}{$\begin{array}{l}\text { Mandel et al. } \\
(2014)\end{array}$} & \multirow[t]{6}{*}{36} & \multirow[t]{6}{*}{44} & \multirow[t]{6}{*}{11.9} & $\begin{array}{l}\text { Radiation: } 2 \\
(5.56)\end{array}$ & 80 & \multirow{6}{*}{$\begin{array}{l}\text { No } \\
\text { statistically } \\
\text { different } \\
\text { KPS }\end{array}$} & \multirow[t]{6}{*}{$\mathrm{N} / \mathrm{A}$} & \multirow[t]{6}{*}{3.5} & \multirow[t]{6}{*}{16.0} \\
\hline & & & & $\begin{array}{l}\text { Chemo: } 3 \\
(8.33)\end{array}$ & & & & & \\
\hline & & & & $\begin{array}{l}\text { Anti- } \\
\text { angiogenic, } \\
\text { chemo: } 13 \\
(36.1)\end{array}$ & & & & & \\
\hline & & & & $\begin{array}{l}\text { Chemo, } \\
\text { Radiation: } 10 \\
(27.8)\end{array}$ & & & & & \\
\hline & & & & $\begin{array}{l}\text { Resection: } 1 \\
(2.78)\end{array}$ & & & & & \\
\hline & & & & $\begin{array}{l}\text { No treatment: } 5 \\
(13.9)\end{array}$ & & & & & \\
\hline \multirow[t]{6}{*}{$\begin{array}{l}\text { Dardis et al. } \\
(2014)\end{array}$} & \multirow[t]{6}{*}{23} & \multirow[t]{6}{*}{50.0} & \multirow[t]{6}{*}{7.9} & $\begin{array}{l}\text { No treatment: } 7 \\
(30.5)\end{array}$ & 70 & \multirow[t]{6}{*}{$\begin{array}{l}>90 \text { (for } \\
\text { treatment) }\end{array}$} & \multirow[t]{6}{*}{ N/A } & \multirow[t]{6}{*}{7.4} & \multirow[t]{6}{*}{17.7} \\
\hline & & & & $\begin{array}{l}\text { IT-Chemo only: } \\
4(17.4)\end{array}$ & & & & & \\
\hline & & & & $\begin{array}{l}\text { IT-Chemo, } \\
\text { radiation: } 2 \\
(8.70)\end{array}$ & & & & & \\
\hline & & & & $\begin{array}{l}\text { Chemo, } \\
\text { Radiation: } 3 \\
(13.0)\end{array}$ & & & & & \\
\hline & & & & $\begin{array}{l}\text { Chemo only: } 4 \\
\text { (17.4) }\end{array}$ & & & & & \\
\hline & & & & $\begin{array}{l}\text { Radiation only: } \\
3(13.0)\end{array}$ & & & & & \\
\hline
\end{tabular}




\begin{tabular}{|c|c|c|c|c|c|c|c|c|c|}
\hline $\begin{array}{l}\text { Study Author } \\
\text { (Year) }\end{array}$ & $\begin{array}{l}\text { Number } \\
\text { of } \\
\text { Patients } \\
\text { with } \\
\text { LMD in } \\
\text { GBM }\end{array}$ & $\begin{array}{l}\text { Median } \\
\text { Age } \\
\text { (Years) }\end{array}$ & $\begin{array}{l}\text { Median } \\
\text { Time to } \\
\text { LMD } \\
\text { diagnosis } \\
\text { (Months) }\end{array}$ & $\begin{array}{l}\text { Treatment } \\
\text { upon LMD } \\
\text { Diagnosis: \# of } \\
\text { patients (\%) }\end{array}$ & $\begin{array}{l}\text { Median } \\
\text { KPS }\end{array}$ & $\begin{array}{l}\text { Median } \\
\text { KPS Post } \\
\text { Intervention }\end{array}$ & $\begin{array}{l}\text { Median } \\
\text { Progression } \\
\text { Free } \\
\text { Survival } \\
\text { (Months) }\end{array}$ & $\begin{array}{l}\text { Median } \\
\text { Survival } \\
\text { Upon } \\
\text { Intervention } \\
\text { (Months) }\end{array}$ & $\begin{array}{l}\text { Median } \\
\text { Overall } \\
\text { Survival } \\
\text { (Months) }\end{array}$ \\
\hline $\begin{array}{l}\text { Kong et al. } \\
\text { (2015) }\end{array}$ & 1 & 36 & 5.0 & $\begin{array}{l}\text { No treatment: } 1 \\
(100)\end{array}$ & $\mathrm{N} / \mathrm{A}$ & $\mathrm{N} / \mathrm{A}$ & $\mathrm{N} / \mathrm{A}$ & 1 & 6 \\
\hline $\begin{array}{l}\text { Okita et al. } \\
\text { (2015) }\end{array}$ & 1 & 28 & N/A & $\begin{array}{l}\text { Anti- } \\
\text { angiogenic, } \\
\text { Chemo: } 1(100)\end{array}$ & $\mathrm{N} / \mathrm{A}$ & $\mathrm{N} / \mathrm{A}$ & 4 & 5 & $\mathrm{~N} / \mathrm{A}$ \\
\hline \multirow[t]{3}{*}{$\begin{array}{l}\text { Noh et al. } \\
\text { (2015) }\end{array}$} & \multirow[t]{3}{*}{75} & \multirow[t]{3}{*}{46.5} & \multirow[t]{3}{*}{12.0} & $\begin{array}{l}\text { 1. IT-Chemo: } 12 \\
\text { (16.0) }\end{array}$ & \multirow[t]{3}{*}{$\mathrm{N} / \mathrm{A}$} & 1. 63.33 & \multirow[t]{3}{*}{$\mathrm{N} / \mathrm{A}$} & 1. 1.6 .0 & 1. 19.4 \\
\hline & & & & $\begin{array}{l}\text { 2. No } \\
\text { Treatment: } 41 \\
(54.7)\end{array}$ & & $\begin{array}{l}2.58 .64 \\
\text { 3. } 56.69\end{array}$ & & $\begin{array}{l}\text { 2. } 2.3 .0 \\
\text { 3. 3. } 6.6\end{array}$ & $\begin{array}{l}2.12 .6 \\
3.13 .4\end{array}$ \\
\hline & & & & $\begin{array}{l}\text { 3. Other } \\
\text { salvage } \\
\text { treatment: } 22 \\
(2.93)\end{array}$ & & & & & \\
\hline $\begin{array}{l}\text { Sharma et al. } \\
(2016) 1\end{array}$ & 1 & 60 & 36.0 & $\begin{array}{l}\text { Radiation: } 1 \\
(100)\end{array}$ & $\mathrm{N} / \mathrm{A}$ & $\mathrm{N} / \mathrm{A}$ & $\mathrm{N} / \mathrm{A}$ & 6.0 & 42.0 \\
\hline \multirow[t]{2}{*}{$\begin{array}{l}\text { Burger et al. } \\
(2016)\end{array}$} & \multirow[t]{2}{*}{4} & \multirow[t]{2}{*}{45.0} & \multirow[t]{2}{*}{16.0} & $\begin{array}{l}\text { Antiangiogenic, } \\
\text { Radiation: } 3 \\
\text { (75.0) }\end{array}$ & \multirow[t]{2}{*}{70} & \multirow[t]{2}{*}{67.5} & \multirow[t]{2}{*}{1.94} & \multirow[t]{2}{*}{3.2} & \multirow[t]{2}{*}{21.0} \\
\hline & & & & $\begin{array}{l}\text { Anti- } \\
\text { angiogenic } \\
\text { only: } 1(25.0)\end{array}$ & & & & & \\
\hline $\begin{array}{l}\text { Nunn et al. } \\
\text { (2017) }\end{array}$ & 1 & 31 & 12.0 & $\begin{array}{l}\text { Anti- } \\
\text { angiogenic, } \\
\text { Chemo: } 1 \text { (100) }\end{array}$ & $\mathrm{N} / \mathrm{A}$ & $\mathrm{N} / \mathrm{A}$ & $\mathrm{N} / \mathrm{A}$ & 2.0 & 14.0 \\
\hline $\begin{array}{l}\text { Serrano et al. } \\
\text { (2017) }\end{array}$ & 1 & 33 & 13.0 & $\begin{array}{l}\text { Laminectomy: } \\
1(100)\end{array}$ & $\mathrm{N} / \mathrm{A}$ & $\mathrm{N} / \mathrm{A}$ & $\mathrm{N} / \mathrm{A}$ & 5.0 & 18.0 \\
\hline \multirow[t]{7}{*}{$\begin{array}{l}\text { Andersen et } \\
\text { al. (2019) }\end{array}$} & \multirow[t]{7}{*}{111} & \multirow[t]{7}{*}{58} & \multirow[t]{7}{*}{11.9} & $\begin{array}{l}\text { Radiation: } 10 \\
(9.01)\end{array}$ & \multirow[t]{7}{*}{70} & $\begin{array}{l}\text { Stop } \\
\text { therapy - } \\
\text { KPS } 60\end{array}$ & \multirow[t]{7}{*}{$\mathrm{N} / \mathrm{A}$} & \multirow[t]{7}{*}{3.8} & \multirow[t]{7}{*}{17.1} \\
\hline & & & & $\begin{array}{l}\text { Chemo: } 32 \\
\text { (28.8) }\end{array}$ & & \multirow[t]{6}{*}{$\begin{array}{l}\text { All therapy - } \\
\text { KPS } 80\end{array}$} & & & \\
\hline & & & & $\begin{array}{l}\text { Anti- } \\
\text { angiogenic: } 35 \\
\text { (31.5) }\end{array}$ & & & & & \\
\hline & & & & $\begin{array}{l}\text { VP Shunt: } 8 \\
(7.21)\end{array}$ & & & & & \\
\hline & & & & $\begin{array}{l}\text { Clinical Trial: } 4 \\
(3.60)\end{array}$ & & & & & \\
\hline & & & & $\begin{array}{l}\text { Target } \\
\text { Therapy: } 7 \\
(6.31)\end{array}$ & & & & & \\
\hline & & & & $\begin{array}{l}\text { No treatment: } \\
36(32.4)\end{array}$ & & & & & \\
\hline $\begin{array}{l}\text { Sibanda et al. } \\
(2020)\end{array}$ & 1 & 57 & 0 & $\begin{array}{l}\text { No treatment: } 1 \\
(100)\end{array}$ & $\mathrm{N} / \mathrm{A}$ & $\mathrm{N} / \mathrm{A}$ & $\mathrm{N} / \mathrm{A}$ & 1.0 & 1.0 \\
\hline
\end{tabular}

A total of 263 patients with glioblastoma were included in the analysis. Among the studies with more than one patient, the median age of the patients ranged from 44-58 years in studies. Median time to leptomeningeal spread from GBM diagnosis ranged from 4.0-16.0 months. Median survival upon intervention for LMD ranged from 2.0-7.4 months. Median overall survival from GBM diagnosis for all patients who developed LMD ranged between 7.0-21.0 months. 
Among the case studies, the time between GBM and LMD diagnosis ranged between 0 months (LMD being diagnosed concurrently with GBM) and 31.0 months, with a median of 1 month. Among these studies, survival after LMD diagnosis ranged between 1 week and 17.0 months, with a median of 7 months.

In total, 92 (30.7\%) patients received no treatment for LMD while 171 (69.3\%) received some form of treatment. Patients received the following therapies: anti-angiogenic therapy in conjunction with any other treatment $(n=54)$, chemotherapy alone $(n=39)$, radiotherapy alone $(n=20)$, both chemotherapy and radiotherapy $(n=14)$, intrathecal chemotherapy in conjunction with any other treatment $(n=19)$, and unspecified treatment $(n=24)$. One patient with focal spinal LMD had a laminectomy.

\section{Discussion}

\section{Incidence of Leptomeningeal Spread in GBM}

The incidence of leptomeningeal dissemination in glioblastoma appears to be on the rise. Previous studies suggest this may be a consequence of advances in GBM treatment and increasing overall survival of glioblastoma patients. A single center retrospective review by Dardis et al. estimated the incidence of leptomeningeal metastases in high grade gliomas to be $3.8 \%$ over ten years at their institution [5]. Andersen et al. in a similar study that included over 4,000 patients with glioma calculated an incidence of $4.7 \%$ [6]. A third study of GBM patients by Mandel et al. found an incidence of $4.0 \%(\mathrm{~N}=595)$ [7]. Notably, the incidence is higher in cerebellar GBM [8]. The majority of spinal dissemination of GBM occurs through leptomeningeal spread; this accounts for a majority of extracranial metastasis of GBM [9, 10]. Leptomeningeal spread in glioblastoma is still likely underreported; the incidence of LMD on autopsy is higher and has been reported to be between $5-27 \%$ in some cases [11-12]. One study reported the prevalence of spinal LMD on autopsy as high as $60 \%$ [13].

Given this discrepancy, LMD is likely an under-recognized downstream result of GBM. In particular, as overall survival improves, the incidence of LMD will likely increase. Treatment of LMD can lead to prolonged survival, and so LMD may represent a more clinically actionable entity for these longer term survivors. As such, this warrants further investigation regarding its possible mechanisms and causes with an eye towards treatment

\section{Diagnosis of LMD in GBM}

The clinical diagnosis of LMD should be considered in all GBM patients presenting with hydrocephalus, particularly communicating hydrocephalus [5]. Spinal LMD can present as radiculopathy or pain in the upper and lower limbs, neck, interscapular area, and lower back [4, 14]. The two most common methods of supporting LMD diagnosis are MRI and cytological CSF analysis [15]. Radiographic criteria for intracranial LMD have been defined as contrast enhancement of the leptomeninges around the outlines of the gyri and sulci or simply new enhancement of the ventricular wall and subarachnoid spaces of the brain $[16,17]$. CSF cytology can also be used but is less sensitive and may require multiple lumbar punctures [6]. PET scans can also be used to make an LMD diagnosis, however this modality is even less commonly utilized than CSF cytology [18].

CSF cytology may surpass MRI as the preferred method of diagnosis if sensitivity is increased; the "liquid biopsy" is one such avenue to increasing accuracy. Liquid biopsy refers to the more sophisticated detection of tumor cells, DNA, and RNA present in CSF and has been shown to be far more sensitive and specific for LMD from systemic malignancy, with sensitivities as high as 100\% and specificity of $97 \%$ [15]. Liquid biopsy methods for GBM are still in development, but could prove to be a useful tool in future treatment of LMD. Another possible diagnostic tool is genomics. Some genomic alterations have been linked to LMD, but due to low power these patterns cannot yet be used as predictors of $\operatorname{LMD}[17,19,20]$. Of course, improvements in diagnosis can only become clinically relevant if optimal adjuvant and surgical treatments are identified.

\section{Adjuvant Treatment of LMD in GBM}

To date there is no standardized treatment or management paradigm for patients with leptomeningeal spread from glioblastoma. Adjuvant treatment options include radiation, anti-angiogenic therapies, as well as both intrathecal (IT) and/or systemic chemotherapy. These treatments are described in Fig. 2. In addition, there are other therapies aimed at treating complications from LMD, such as ventriculoperitoneal (VP) shunts to manage hydrocephalus in these patients. The prognosis for patients with LMD in glioblastoma is poor, with one study reporting a mean survival of 3.8 months from the point of LMD diagnosis $(N=103)$ [6].

The aforesaid treatments have been shown to improve survival in several studies [5-7]. Andersen et al. reported patients with glioblastoma who underwent any therapy for LMD had a survival of 5.0 months following LMD diagnosis compared to 1.6 months in those with no treatment. This improvement in survival was coupled with an improvement in KPS score [6]. Patients who underwent radiotherapy and clinical trial therapy had the longest survival with both at 7.6 months. However, survival among all forms of therapy did not differ at a level of statistical significance $(p=0.33)$. By contrast, Mandel et al. showed that patients who underwent both chemotherapy and radiotherapy had

Page $6 / 13$ 
increased survival compared to no treatment but without corresponding increase in KPS score [7]. Dardis et al. reported improved outcomes in survival as well, with some form of treatment having an overall survival of 11.7 months compared to only 3.3 months if no treatment was given $(p<0.001)$ [5]. While the studies differed in reporting how much any single treatment improved survival, all studies showed that each form of treatment significantly improved survival compared to no treatment. This improvement in survival may be significant for patients, especially if functional performance is preserved, and warrants further investigation.

Various modalities of radiotherapy have been used to treat LMD including intensity-modulated radiotherapy, whole-brain radiotherapy, or whole-spine radiotherapy $[6,21]$. One study by Dardis et al. recommends radiotherapy at the highest tolerated dose [5]. They report that for LMD in the brain, whole-brain radiation is the preferred method [5]. Doses as high as 59 Gy have been used in some patients and have been shown to decrease rates of development of LMD [22-23].

Radiotherapy also appears to improve survival when used in conjunction with other therapies. Dardis et al. recommends combining radiotherapy with an alkylating agent for best results [5]. Mandel et al. documented similar findings, reporting that a combination of chemotherapy and radiotherapy led to prolonged overall survival of 7.7 months, which was increased compared to monotherapy or supportive care $[7,24]$. Kwon et al. found that given the aggressive nature of LMD, patients who are diagnosed with LMD at the time of GBM diagnosis should undergo radiotherapy and chemotherapy earlier and more aggressively than in patients without LMD [25]. The low prevalence of LMD has proven to be an obstacle in examining the efficacy of various treatments. The increasing proportion of longer term GBM survivors may be able to power such a study.

Several case studies have reported transient improvement in performance with systemic chemotherapy and bevacizumab (BEV), an antiangiogenic agent [26-28]. Bevacizumab acts against VEGF and can normalize disrupted tumor vasculature [26, 28]. However, recent studies have shown this effect on LMD to be somewhat limited. Burger et al. showed that 3 out of 4 patients did not respond well to anti-angiogenic therapy and had no improvement in KPS score [26]. There has been concern that anti-angiogenic therapy may actually predispose patients to developing LMD by activating invasive cellular programs [7]. However, Andersen et al. showed no such correlation, noting that more research is needed to investigate the link between anti-angiogenic therapy and LMD [6]. At this time, chemotherapy in conjunction with radiotherapy shows more promise for a survival benefit than with antiangiogenic chemotherapy.

Intrathecal chemotherapy, specifically intrathecal methotrexate (IT-MTX), has been used for treatment of LMD [29]. Intrathecal methotrexate has been used to treat LMD in patients with lymphoma, breast cancer, and lung cancer with success [30]. Noh et al. found that survival in GBM patients who received this treatment was significantly increased with an overall survival of 181 days compared to 91 days with no treatment $(p=0.039)$ [31]. Additionally, the patients who received IT-MTX therapy did not show an improvement in their KPS scores compared to those who underwent other treatment or those who underwent conservative treatment [31].

Dardis et al. reported data on patients who received intrathecal chemotherapy for LMD. They noted that only three of nine patients underwent six weeks of therapy before their LMD progressed [5]. Four of these patients did have VP shunts placed during or prior to their intrathecal chemotherapy, potentially limiting the effectiveness of the therapy. Other chemotherapeutic agents such as IT thio-TEPA, an alkylating agent, have been used with success in small samples. This treatment increased survival to 10 months with corresponding improvement noted on radiologic imaging [32].

Effective administration of chemotherapy to the CSF could be useful in treatment of LMD. In vitro magnetic nanoparticles have been used to deliver chemotherapy agents such as etoposide to CSF pathways; glioblastoma cells were particularly susceptible to this method of delivery [33]. Immunotherapy has also been considered in treatment of LMD. In a patient with multifocal LMD, administration of CAR T cells showed a sustained regression of tumor for 7.5 months [34].

\section{Surgical Treatment of LMD in GBM Hydrocephalus and VP Shunt}

Symptomatic treatment in patients with LMD may lead to improvements in quality of life. Patients with LMD in glioblastoma can develop hydrocephalus due to impaired CSF resorption [35]. The development of communicating hydrocephalus in GBM patients has been shown to correlate with the presence of leptomeningeal dissemination [36]. Inamasu et al. discovered that all patients who presented with postoperative communicating hydrocephalus had evidence of leptomeningeal dissemination [37]. Basically, if a patient has communicating hydrocephalus following GBM resection, the diagnosis of LMD is near certain; but LMD itself does not necessarily cause hydrocephalus.

Notably, Onuma et al. reported that median survival in GBM patients with LMD is longer in patients without communicating hydrocephalus [38]. Treatment of hydrocephalus with VP or lumboperitoneal shunt in patients with LMD has been shown to improve survival [39]. Thus, management of hydrocephalus is important in treatment of LMD despite the unclear mechanism by which LMD develops. 
Treating hydrocephalus in LMD patients can be difficult. Woo et al. describes an LMD patient treated with VP shunt who subsequently developed shunt obstruction due to progressive LMD. Intraventricular urokinase restored shunt patency with subsequent improvement of hydrocephalus and symptoms [40]. Onuma et al. noted that, while VP shunt surgery did not improve KPS in 10 GBM patients with hydrocephalus, 6 of 10 patients did experience subjective improvement in symptoms [38]. Kwon et al. also noted that patients experienced less pain following CSF diversion [25]. Given that treatment at this stage of GBM is supportive and not curative, symptomatic improvement is significant for patients and should be considered by neuro-oncologists in concert with neurosurgeons.

\section{Hybrid Approach}

Patients with both intrathecal chemotherapy for management of LMD and VP shunts for hydrocephalus present a unique challenge. Shunts divert CSF and therefore can also divert intrathecal chemotherapy, limiting the effect of treatment [41]. However, both intrathecal chemotherapy and treatment of hydrocephalus with VP shunt can improve survival and symptoms in certain patients. Providing both treatments concurrently represents a challenge for neuro-oncologists.

A conceptually simple solution for this problem has been presented: deploy VP shunts with on-off valves [41, 42]. This would allow the VP shunt to drain CSF in cases of hydrocephalus. Then, when intrathecal chemotherapy is administered, the VP shunt can be turned off so that the agents can be distributed in CSF normally [42]. A schematic for an on/off valve in combination with the ventricular shunting system is shown in Fig. 3. These shunts were reported as easy to turn on and off and as a useful tool in treatment of LMD. No operative difficulty, perioperative morbidity, or perioperative mortality were reported [42]. This ability to treat both the LMD and hydrocephalus concurrently is an important therapeutic option for LMD patients and may be considered by the neuro-oncologists and neurosurgeons on a case-by-case basis.

\section{Conclusion}

Treatment of LMD in the setting of GBM remains a highly controversial topic. Given the historically poor prognosis from GBM, there is a collective lack of momentum among neuro-oncologists and neurosurgeons towards intervention. Many treating physicians view LMD in GBM as a terminal situation. However, there is a growing body of evidence, albeit retrospective, that adjuvant therapy and even surgery can increase overall survival and improve performance status. These therapies have demonstrated the ability to improve survival and KPS more than conservative management. Although there is not one treatment that has shown to be associated with better outcomes or increased survival, there is some evidence to support strong consideration of one or more treatment modalities on a patient-specific basis. Chemotherapy in conjunction with radiotherapy, as well as intrathecal chemotherapy, appear especially promising in this regard. GBM is a genetically heterogeneous entity and it is entirely possible that a range of therapies may be needed depending on known and as yet undiscovered properties.

The decision to put a GBM patient through additional treatment, and potentially more surgery, is a difficult one and will obviously be tailored to the individual patient based on age, performance status, and stated wishes. But as more patients live beyond the traditional survival window with GBM, these therapeutic strategies will become more prevalent. We believe that the current literature is suggestive of a growing tendency towards treating these patients. However, it bears repeating that these are very sick patients with limited life expectancy. As such, small target-driven treatments, based on precision medicine and immunological analysis, are more realistic and achievable. Indeed, prospective multi-institutional studies with large patient samples are necessary to advance a standard of care for these patients, though we will almost certainly view the decision to intervene as a highly individualized moment.

\section{Limitations}

Any review or meta analysis of LMD in GBM is limited by the lack of literature and data available. It is difficult to make conclusions on treatment and survival benefits across a handful of case reports and retrospective reviews. Our intention with this review was to provide insight into current and future trends in treatment of LMD. Higher powered studies will be needed in the future to make more definitive conclusions.

\section{Abbreviations}

GBM - glioblastoma multiforme, LMD - leptomeningeal disease, CSF - cerebrospinal fluid, KPS - Karnofsky Performance Status, WBRT - whole brain radiotherapy, BEV - Bevacizumab, VEGF - vascular endothelial growth factor, IT-MTX - intrathecal methotrexate, VP - ventriculoperitoneal

\section{Declarations}

\section{Funding}


Not applicable.

\section{Conflicts of interest/Competing interests}

On behalf of all authors, the corresponding author states that there is no conflict of interest.

\section{Availability of data and material}

Not applicable.

\section{Code availability}

Not applicable.

\section{Ethics approval}

Not applicable.

\section{Consent to participate}

Not applicable.

\section{Consent for Publication}

Not applicable.

\section{Author's Contributions}

All authors contributed to the study conception and design. Data collection and analysis were performed by Sarfraz Akmal and Elizabeth Ginalis. The first draft of the manuscript was written by Sarfraz Akmal and all authors commented on previous versions of the manuscript. All authors read and approved the final manuscript.

\section{References}

1. Zong H, Parada LF, Baker SJ (2015) Cell of Origin for Malignant Gliomas and Its Implication in Therapeutic Development. Cold Spring Harb Perspect Biol 7:a020610. https://doi.org/10.1101/cshperspect.a020610

2. lacob G, Dinca EB (2009) Current data and strategy in glioblastoma multiforme. J Med Life 2:386-393

3. Young RM, Jamshidi A, Davis G, Sherman JH (2015) Current trends in the surgical management and treatment of adult glioblastoma. Ann Transl Med 3:121. https://doi.org/10.3978/j.issn.2305-5839.2015.05.10

4. Goel A, Shah A, Redhu R, Nadkarni T (2010) Supratentorial glioblastoma multiforme with spinal metastases. J Craniovertebral Junction Spine 1:126. https://doi.org/10.4103/0974-8237.77678

5. Dardis C, Milton K, Ashby L, Shapiro W (2014) Leptomeningeal Metastases in High-Grade Adult Glioma: Development, Diagnosis, Management, and Outcomes in a Series of 34 Patients. Front Neurol 5:. https://doi.org/10.3389/fneur.2014.00220

6. Andersen BM, Miranda C, Hatzoglou V, et al (2019) Leptomeningeal metastases in glioma: The Memorial Sloan Kettering Cancer Center experience. Neurology 92:e2483-e2491. https://doi.org/10.1212/WNL.0000000000007529

7. Mandel JJ, Yust-Katz S, Cachia D, et al (2014) Leptomeningeal dissemination in glioblastoma; an inspection of risk factors, treatment, and outcomes at a single institution. J Neurooncol 120:597-605. https://doi.org/10.1007/s11060-014-1592-1

8. Vollmer K, Pantazis G, Añon J, et al (2019) Spinal Metastases of Supratentorial Glioblastoma with Primitive Neuronal Component. World Neurosurg X 2:100019. https://doi.org/10.1016/j.wnsx.2019.100019

9. Amitendu S, Mak SKD, Ling JM, Ng WH (2012) A single institution experience of the incidence of extracranial metastasis in glioma. J Clin Neurosci 19:1511-1515. https://doi.org/10.1016/j.jocn.2011.08.040

10. Sibanda Z, Farahani N, Ogbonnaya E, Albanese E (2020) Glioblastoma Multiforme: A Rare Case of Spinal Drop Metastasis. World Neurosurg 144:24-27. https://doi.org/10.1016/j.wneu.2020.08.086 
11. Schwartz C, Romagna A, Machegger L, et al (2018) Extensive Leptomeningeal Intracranial and Spinal Metastases in a Patient with a Supratentorial Glioblastoma Multiforme, IDH-Wildtype. World Neurosurg 120:442-447. https://doi.org/10.1016/j.wneu.2018.09.082

12. Masters LT, Miller DC, Nelson PK (2000) Cerebral vasculopathy secondary to leptomeningeal gliomatosis: angiography. Neuroradiology 42:139-141. https://doi.org/10.1007/s002340050033

13. Serrano L, Archavlis E, Januschek E, et al (2017) Spinal Intradural Intramedullary Dissemination in the Absence of Intracranial Relapse of a Previously Radically Treated Temporal Lobe Glioblastoma Multiforme. Case Rep Oncol 10:281-289. https://doi.org/10.1159/000464279

14. Witoonpanich P, Bamrungrak K, Jinawath A, et al (2011) Glioblastoma multiforme at the corpus callosum with spinal leptomeningeal metastasis. Clin Neurol Neurosurg 113:407-410. https://doi.org/10.1016/j.clineuro.2010.12.001

15. Birzu C, Tran S, Bielle F, et al (2020) Leptomeningeal Spread in Glioblastoma: Diagnostic and Therapeutic Challenges. The Oncologist 25:. https://doi.org/10.1634/theoncologist.2020-0258

16. Mistry AM, Kelly PD, Gallant J-N, et al (2019) Comparative Analysis of Subventricular Zone Glioblastoma Contact and Ventricular Entry During Resection in Predicting Dissemination, Hydrocephalus, and Survival. Neurosurgery 85:E924-E932.

https://doi.org/10.1093/neuros/nyz144

17. You HJ, Park H-Y, Kim J, et al (2016) Integrative radiogenomic analysis for genomic signatures in glioblastomas presenting leptomeningeal dissemination: Medicine (Baltimore) 95:e4109. https://doi.org/10.1097/MD.0000000000004109

18. Intriago B, Danús M, Añaños M, et al (2011) 18F-FDG PET detection of spinal leptomeningeal metastases from cerebral glioblastoma multiforme. Eur J Nucl Med Mol Imaging 38:1392-1392. https://doi.org/10.1007/s00259-011-1750-Z

19. Alnahhas I, Guillermo Prieto Eibl P, Gonzalez J, et al (2019) Leptomeningeal spread of glioma in the molecular era. J Clin Oncol 37:e13537-e13537. https://doi.org/10.1200/JC0.2019.37.15_suppl.e13537

20. Korshunov A, Sycheva R, Golanov A, Pronin I (2007) Gains at the 1p36 Chromosomal Region Are Associated With Symptomatic Leptomeningeal Dissemination of Supratentorial Glioblastomas. Am J Clin Pathol 127:585-590. https://doi.org/10.1309/DE4LNX3YMACCC1ER

21. Nunn A, Polyzoidis S, Piechowski-Jozwiak B, et al (2017) Primary glioblastoma multiforme of the conus medullaris with leptomeningeal metastasis. J Neurol Sci 381:315-317. https://doi.org/10.1016/j.jns.2017.09.004

22. Broniscer A, Chintagumpala M, Fouladi M, et al (2006) Temozolomide after Radiotherapy for Newly Diagnosed High-grade Glioma and Unfavorable Low-grade Glioma in Children. J Neurooncol 76:313-319. https://doi.org/10.1007/s11060-005-7409-5

23. Routman DM, Yan E, Vora S, et al (2018) Preoperative Stereotactic Radiosurgery for Brain Metastases. Front Neurol 9:959. https://doi.org/10.3389/fneur.2018.00959

24. Buszek SM, Chung C (2019) Radiotherapy in Leptomeningeal Disease: A Systematic Review of Randomized and Non-randomized Trials. Front Oncol 9:. https://doi.org/10.3389/fonc.2019.01224

25. Kwon J-E, Hwang K, Go K-O, et al (2020) Clinical Characteristics of High-Grade Glioma with Primary Leptomeningeal Seeding at Initial Diagnosis in a Single Center Study. Brain Tumor Res Treat 8:77. https://doi.org/10.14791/btrt.2020.8.e18

26. Burger MC, Zeiner PS, Jahnke K, et al (2016) Addition of Anti-Angiogenetic Therapy with Bevacizumab to Chemo- and Radiotherapy for Leptomeningeal Metastases in Primary Brain Tumors. PLOS ONE 11:e0155315. https://doi.org/10.1371/journal.pone.0155315

27. Toh CH, Liau C-T, Wei K-C, Castillo M (2019) Baseline multicentric tumors, distant recurrences and leptomeningeal dissemination predict poor survival in patients with recurrent glioblastomas receiving bevacizumab. J Neurooncol 142:149-159. https://doi.org/10.1007/s11060018-03075-x

28. Okita Y, Nonaka M, Umehara T, et al (2015) Efficacy of temozolomide and bevacizumab for the treatment of leptomeningeal dissemination of recurrent glioblastoma: A case report. Oncol Lett 9:1885-1888. https://doi.org/10.3892/ol.2015.2940

29. Engelhard HH, Corsten LA (2005) Leptomeningeal Metastasis of Primary Central Nervous System (CNS) Neoplasms. In: Abrey LE, Chamberlain MC, Engelhard HH (eds) Leptomeningeal Metastases. Springer-Verlag, New York, pp 71-85 
30. Herrlinger U, Förschler H, Küker W, et al (2004) Leptomeningeal metastasis: survival and prognostic factors in 155 patients. J Neurol Sci 223:167-178. https://doi.org/10.1016/j.jns.2004.05.008

31. Noh J-H, Lee MH, Kim WS, et al (2015) Optimal treatment of leptomeningeal spread in glioblastoma: analysis of risk factors and outcome. Acta Neurochir (Wien) 157:569-576. https://doi.org/10.1007/s00701-015-2344-5

32. Witham TF, Fukui MB, Meltzer CC, et al (1999) Survival of patients with high grade glioma treated with intrathecal thiotriethylenephosphoramide for ependymal or leptomeningeal gliomatosis. Cancer 86:1347-1353. https://doi.org/10.1002/(sici)10970142(19991001)86:7<1347::aid-cncr34>3.0.co;2-m

33. Engelhard HH, Willis AJ, Hussain SI, et al (2020) Etoposide-Bound Magnetic Nanoparticles Designed for Remote Targeting of Cancer Cells Disseminated Within Cerebrospinal Fluid Pathways. Front Neurol 11:596632. https://doi.org/10.3389/fneur.2020.596632

34. Brown CE, Alizadeh D, Starr R, et al (2016) Regression of Glioblastoma after Chimeric Antigen Receptor T-Cell Therapy. N Engl J Med 375:2561-2569. https://doi.org/10.1056/nejmoa1610497

35. Hong B, Polemikos M, Heissler HE, et al (2018) Challenges in cerebrospinal fluid shunting in patients with glioblastoma. Fluids Barriers CNS 15:16. https://doi.org/10.1186/s12987-018-0101-x

36. Fischer CM, Neidert MC, Péus D, et al (2014) Hydrocephalus after resection and adjuvant radiochemotherapy in patients with glioblastoma. Clin Neurol Neurosurg 120:27-31. https://doi.org/10.1016/j.clineuro.2014.02.012

37. Inamasu J, Nakamura Y, Saito R, et al (2003) Postoperative communicating hydrocephalus in patients with supratentorial malignant glioma. Clin Neurol Neurosurg 106:9-15. https://doi.org/10.1016/S0303-8467(03)00060-X

38. Onuma K, Ishikawa E, Matsuda M, et al (2013) Clinical Characteristics and Neuroimaging Findings in 12 Cases of Recurrent Glioblastoma With Communicating Hydrocephalus. Neurol Med Chir (Tokyo) 53:474-481. https://doi.org/10.2176/nmc.53.474

39. Kim HS, Park JB, Gwak H-S, et al (2019) Clinical outcome of cerebrospinal fluid shunts in patients with leptomeningeal carcinomatosis. World J Surg Oncol 17:. https://doi.org/10.1186/s12957-019-1595-7

40. Woo PYM, Zhuang JTF, Ho JMK, et al (2018) Intraventricular urokinase to treat a blocked ventriculoperitoneal shunt in a glioblastoma patient with leptomeningeal spread. Acta Neurochir (Wien) 160:1073-1077. https://doi.org/10.1007/s00701-018-3509-9

41. Zada G, Chen TC (2010) A Novel Method for Administering Intrathecal Chemotherapy in Patients With Leptomeningeal Metastases and Shunted Hydrocephalus: Case Report. Oper Neurosurg 67:ons-ons. https://doi.org/10.1227/01.neu.0000383138.78632.ba

42. Burger M, Wagner M, Franz K, et al (2018) Ventriculoperitoneal Shunts Equipped with On-Off Valves for Intraventricular Therapies in Patients with Communicating Hydrocephalus due to Leptomeningeal Metastases. J Clin Med 7:216. https://doi.org/10.3390/jcm7080216

\section{Figures}




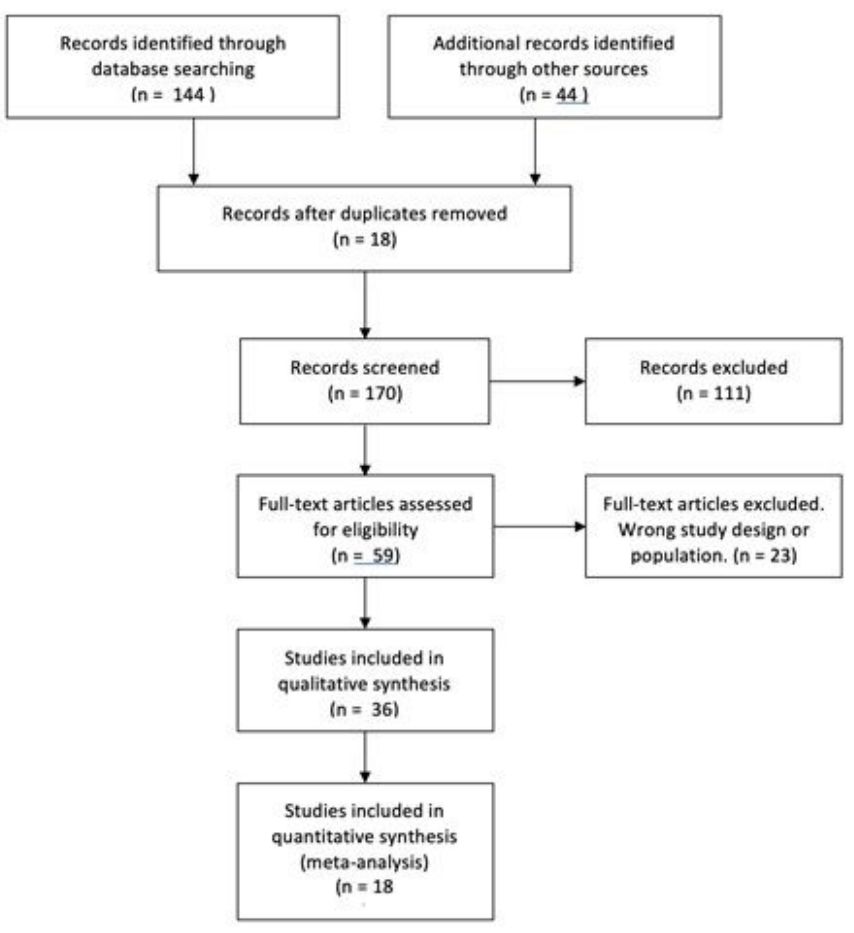

Figure 1

PRISMA Flow Diagram of Article Selection Process

Adjuvant Treatment of LMD

? Radiation

? Brain: Whole brain 30-60 Gy

? Stupp Protocol

? Systemic chemotherapy

? Temozolomide

? Anti-angiogenic therapy

? Bevacizumab

? Immunother apy (CAR T cells)

? Intrathecal chemotherapy

? IT-Methotrexate, IT-Depocyt, IT thio-TEPA

\section{Surgical Treatment of LMD}

? Ommaya reservoir for intrathecal drug delivery

? VP shunt to manage hydrocephalus

? Combined strategies (VPS + Ommaya)

? Laminectomy for focal spinal LMD

\section{Figure 2}

Treatment options for LMD from GBM 


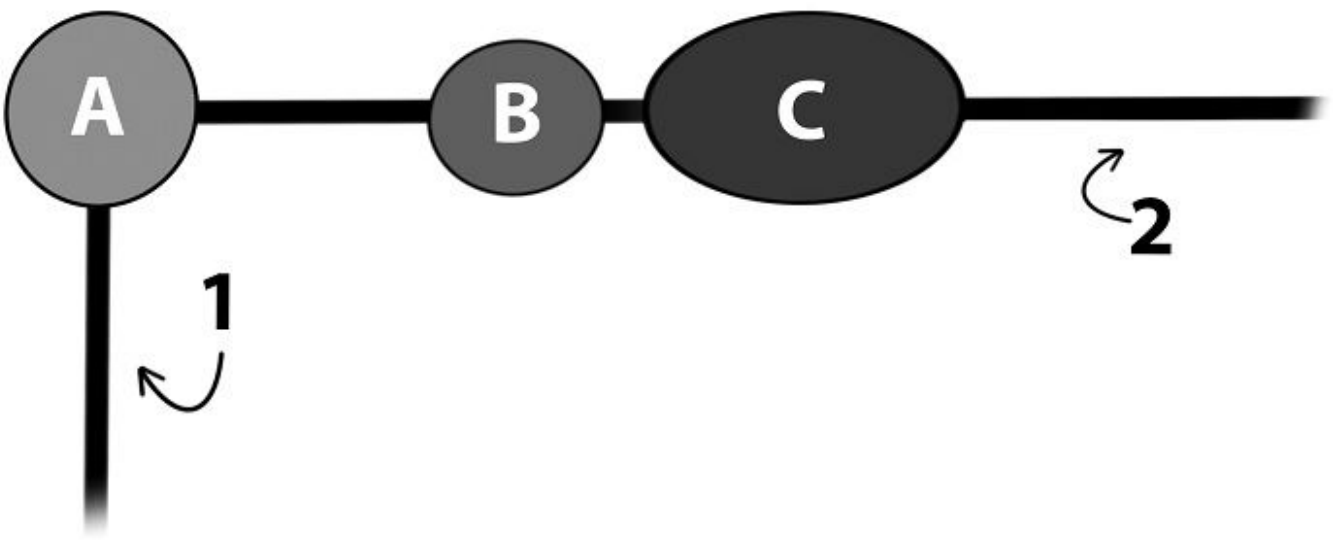

Caption: The proximal (ventricular) catheter is represented by \#1, while the distal (peritoneal, atrial, or pleural) catheter is represented by \#2. A = Ventricular catheter attachment to shunt system via a Rickham or Ommaya type reservoir. B = Proposed On/Off button. C = Standard Programmable Shunt Valve.

When " $\mathrm{B}$ " is turned off, the reservoir " $\mathrm{A}$ " can be accessed for drug delivery into the ventricles via the proximal shunt tubing "1". Then "B" is turned back on to re-establish the normal flow of the shunt from 1 to 2 .

Figure 3

Schematic of On/Off Valve In Combination with Ventricular Shunting System 